\title{
A Comparative Study of Cadastre 2014 and the Zimbabwean Cadastral System
}

\author{
Robert T Mapamula $^{1}$, Charles Paradzayi ${ }^{1}$, Edward Kurwakumire $^{2}$ \\ ${ }^{1}$ Department of Surveying and Geomatics, Midlands State University, Gweru, Zimbabwe, \\ mapamulart@msu.ac.zw \\ ${ }^{2}$ Geomatics Department, Tshwane University of Technology, Pretoria, South Africa
}

DOI: http://dx.doi.org/10.4314/sajg.v5i1.3

\begin{abstract}
The global trend in land information management over the last two decades has been to migrate from paper to computer based information systems. Notable concepts in this regard are: Cadastre 2014, Core Cadastral Domain Model, Land Administration Domain Model (LADM) and subsequent related works. In Zimbabwe, although some concepts in these guidelines manifest in most recent policy documents such as the Zimbabwe Agenda for Sustainable Socio-Economic Transformation (ZimAsset), there has been no deliberate effort to implement them in a holistic and structured manner. This has resulted in fragmented solutions that have failed to meet the requirements of modern land information systems. A case study approach was adopted to gather information from stakeholders working within the Department of the Surveyor General, Deeds Registry, Local Planning Authorities and also including private practitioners involved in the cadastral system. In order to document and describe the existing cadastral framework in the country, an investigation through review of the relevant scholarly articles, policy documents and government reports was carried out, followed by interviews and questionnaires targeted at the major stakeholders. The underlying concepts of the cadastral framework in terms of its operation and workflows were investigated and compared with the Cadastre 2014 conceptual framework. Results indicated that no significant strides have been made in Zimbabwe towards implementing the six statements of Cadastre 2014 and other related best practice standards. This paper is useful as background for any research that will be done on the Zimbabwean cadastre. However, currently there is some momentum towards realisation of new tenure arrangements, review of land survey records and the capturing of cadastral information in a digital environment. This paper contributes to the body of knowledge of cadastral systems in the Zimbabwean context and in the world at large.
\end{abstract}




\section{Introduction}

The relationship between mankind and land goes back to time immemorial. The nature of this relationship changes with time, as society evolves (Bevin, 1999) and has manifested itself through various forms of land tenure. The land tenure system in Zimbabwe recognises both public and private ownership of land. Land rights can be held under (i) freehold tenure, (ii) leasehold tenure, (iii) communal tenure, (iv) easement, (v) resettlement permit tenure, (vi) state land, or (vii) unalienated land (Paradzayi, 2007).

Cadastres have become essential tools for administering land tenure (Williamson, 2001). Efficient and effective cadastres play significant roles in the social and economic development of communities and the nation at large. Such cadastres ensure timeous land transactions by providing one-stop shops and enhanced quality of service from cadastral systems (Chimhamhiwa, 2002). In the concluding part of the $20^{\text {th }}$ century, traditional cadastres were increasingly confronted with rapid developments in technology as well as a growing demand for new services (Van der Molen 2006) bringing about the need for cadastres to evolve and cadastral offices to become service oriented. Cadastral reforms became inevitable and the lack of standards to implement such reforms at the international level also became apparent. Consequently international guidelines and standards were developed to guide cadastral and land administration system reforms. The International Federation of Surveyors (FIG) published the 'Cadastre 2014: A vision for future cadastral systems' (Kaufmann and Steudler, 1998).

The Zimbabwe cadastral system operates largely on a manual framework, although efforts have been made in both the Department of the Surveyor General and the Deeds Registry, to digitalise some of the operational procedures. There were efforts to set up the Zimbabwe Spatial Data Infrastructure from the late 1980s until the mid-2000s (Paradzayi, 2005). However, Zimbabwe experienced an unprecedented economic meltdown between 2000 and 2008 (Dekker, 2009) that almost paralysed most government operations (Jones, 2010). The economic meltdown resulted in human resource shortages in the public sector as many experts migrated to neighbouring countries such as South Africa, Botswana and Namibia in search of greener pastures. In particular, this period of hyperinflation saw the collapse of systems that had been implemented in the Department of the Surveyor General and the death of the Zimbabwe Spatial Data Infrastructure initiative. This resulted in retarded harmonisation of the Zimbabwe land administration system with emerging trends such as visions encompassed in Cadastre 2014 document. Land administration stakeholders within the Zimbabwean context realise the importance of benchmarking the cadastral system against standard and best practices models such as Cadastre 2014 and the land administration domain model (LADM).

In order to find ways to resuscitate economic growth and wealth creation for the nation, the Government of Zimbabwe adopted a new economic blueprint in October 2013. According to the blueprint all sections and levels of government should be automated and integrated in an egovernment environment. Land information constitutes close to seventy percent of all government related information and accounts for between half and three quarters of national wealth according to 
(World Bank, 2006). In order to efficiently manage this information while ensuring timely access, there is need to develop a modern cadastre based on international models and best practices as recommended by (Kurwakumire and Kuzhazha, 2015). Best practices and lessons learnt from prior implementations should be the backbone and flagship of such an initiative to ensure a high probability for successful implementation. The cadastre provides information which facilitates land transactions whose revenue is significant in supporting various government operations which promote social and economic development of the nation.

Some of the concepts contained in the statements contained in the Cadastre 2014 vision are scattered across many Zimbabwean land related policy documents. Zimbabwe's National Land Policy, The Ministry of Lands and Rural Resettlement (MLRR) 2014 to 2016 Action plan and the ZimAsset policy document all adopt international best practices in land administration but with no clear strategies for the implementation. On the other hand, the policies are coordinated in isolation when they benefit more, from administration in a collaborative environment. This has resulted in incomplete solutions that have failed to meet the broad requirements of a modern land administration system. Local planning authorities, Department of the Surveyor General and Deeds Registry have in the past, developed separate information systems that are incompatible and unconnected due to different operating systems, data structures and application software (Chimhamhiwa, 2006). The Department of the Surveyor General has for example made use of, a Microsoft Access ${ }^{\mathrm{TM}}$ based database for attribute information referred to as land transaction system and watermark imaging database for scanned images of cadastral parcels (Kurwakumire and Kuzhazha, 2015).

A well-structured and integrated approach is required in the land administration reforms to support the progression towards e-governance in the country. This calls for a review of the existing cadastral framework and an analysis of the strategies, best practices and lessons learnt from other parts of the world. The development of the Zimbabwe's cadastral system must draw from such input and from experiences gained from other countries. This research seeks to establish and identify gaps in the existing land administration framework and basing on strategies obtained from different parts of the world and develop a set of recommendations towards the meeting cadastre 2014 standards and the development of a modern land administration system in Zimbabwe.

\section{Problem Context}

The land administration system in Zimbabwe has been operational since the late 1890s (Kurwakumire and Chaminama, 2012) and has evolved to what it is nowadays in practice and concept-wise. The technical, legal and institutional arrangements were designed in tandem with the available technology to meet the land management requirements at that time. Over the years different departments have adopted separate strategies for adapting to changing user requirements and technological developments. 
Automated systems for storing and managing land information were introduced in the latter part of the $20^{\text {th }}$ century. However, data exchange between different organisations in Zimbabwe, is mainly based on manual transfer of files (Paradzayi et al., 2014). The interconnectivity of the different systems poses considerable challenges due to the isolated conceptualisation, different operating systems and application software (Chimhamhiwa, 2006). This challenge has effectively limited the benefits that modern technology can introduce to the overall land administration system. Furthermore, policy and legal reforms have focused on the separate organisations without addressing the broad land administration objectives. Modern day user expectations from land administration organisations, demand a more integrated and interoperable approach to land information systems. In addition, other drivers of change such as globalisation, sustainable development and environmental concerns further expose the weaknesses of fragmented systems.

The development of international standards and concepts such as Cadastre 2014, CCDM and LADM among others, was necessitated by the need to eliminate such problems in the administration of land and management of land related resources. These concepts and standards have been adopted and used successfully in different parts of the world to develop integrated systems that address the broad requirements of a modern land information system (van Der Molen, 2014; Kaufmann 2014; Steudler, 2014).

The focus on this paper is in making comparison of the Zimbabwe land administration situation to the dimensions stipulated in the Cadastre 2014 vision. This study is based on literature, a field study and personal experience of the authors in order to develop a set of recommendations towards further development of a modern land administration system in Zimbabwe. The cadastre 2014 statements are discussed in detail in section 3 and CCDM concept in section 4.

\section{Cadastre 2014}

Kaufmann (1999) defines Cadastre 2014 as "a methodically arranged public inventory of data concerning all legal land objects in a certain country or district, based on a survey of their boundaries". A number of observers agree that the visionary statements of the Cadastre 2104 concept remain relevant in modern day cadastral systems (Bennett, 2014; Kaufmann, 2014; Steudler 2014). There are six visionary statements at the core of Cadastre 2014 concept (Kaufmann and Steudler, 1998).

\subsection{Statement 1 - Cadastre 2014 will show the complete legal situation of land, including public rights and restrictions}

The first statement of Cadastre 2014 proposed the inclusion of all rights that are created by public law in the cadastre. The argument was that the existing cadastres in which only private land rights are documented are inadequate to show the true legal situation affecting a registered property. Interested 
citizens and organisations must make further efforts to get information about other rights and restrictions that have an effect on the legal situation by making a survey at different government organisations (Kaufmann and Steudler, 1998). Countries that have embraced this concept include Britain where the National Land Information Service uses new technologies to bring together online, and to make available via one portal, all information that is likely to be of interest to customers. Many developed countries have re-engineered cadastral services and stakeholders can visit one stop shops to settle land property affairs (Kaufmann, 2014).

\subsection{Statement 2 - Separation between maps and registers will be abolished}

The second statement of Cadastre 2014 addresses the aspect of the separation between the organisations that are responsible for cadastral surveying and land registration. Many developed countries have integrated the cadastre and land registry into one organisation since the inception of Cadastre 2014 and in particular, statement 2. Even countries with a history of a dual agency model, such as the Czech Republic, Hungary, Slovakia, Romania and Serbia have established a single agency approach. However, some countries such as Croatia, Slovenia, Bulgaria, Britain and Ukraine retain dual systems but they have linked cadastre and registration systems. The link is through common and unique parcel identifiers which are then used to access to both systems (Adlington, 2014).

\subsection{Statement 3 - Cadastral mapping will be dead. Long live modelling}

Cadastral data modelling as opposed to cadastral mapping is advocated for by the third statement of cadastre 2014. Surveyors were encouraged to think in terms of modelling cadastral objects in ways that are compatible with modern information technologies. Although most countries were hesitant to implement this concept, others like Switzerland have since developed the INTERLIS data model in line with this statement (Steudler, 2014). The International Federation of Surveyors (FIG) has developed the Land Administration Domain Model (LADM) which was been accepted as an international standard (ISO 19152) cadastral data model in November 2012 (Lemmen, 2012). The model has since been tested in some developed nations to include Portugal, Netherlands and China and is now the internationally accepted best practice in cadastral data modelling (Lemmen, 2012).

\subsection{Statement 4 - Paper and pencil cadastre have gone}

The fourth statement of Cadastre 2014 advocates for the cadastre to provide the basic data model. In essence, the paper and pencil cadastre will no longer relevant. Information is created and stored in digital form for entry into the cadastre. The cadastre provides the basic data model which regulates the standard of input from different land administration practitioners. In both developed and developing countries there are no cadastral development projects without extensive information technology (IT) component. However, IT solutions until today often handle the textual and graphical cadastral data separately and the term cadastral map is still used frequently (Kaufmann, 2014). 
3.5 Statement 5 - Cadastre 2014 will be highly privatised. Private and public sector are working closely together

The nature of cadastral and land registration data is such it is authoritative in the sense that the data has legal consequences. There is need for assurance that the data will be available in future and historically as it can take several years before transfers can be done to a particular piece of land, for example, state land can have a duration of hundreds of years before being transferred to a municipality to fulfil objectives of some public interest. Only an organisation with a long term existence and continuity is eligible to secure the existence and the quality of the cadastral data over a long time (Kaufmann, 2014). Statement five of Cadastre 2014 envisioned outsourcing of many tasks that are undertaken in the cadastral domain to the private sector. In many developing countries land transaction contracts are prepared by private notaries and the surveying work is outsourced to private surveyors. These professionals and or organisations, however, would have to undergo a licensing procedure. Practically, all World Bank projects on cadastre and land registration foresee the involvement of the private sector mainly to make better use of the resources and to keep the finance load for the state budgets at a reasonable level (Kaufmann 2014). In South Korea, a government association has exclusively carried out cadastral work until 2004, but since then, the proportion of private sector work has increased to a share of thirty percent (Jang and Koh, 2014).

\subsection{Statement 6 - Cadastre 2014 will be cost recovering}

The awareness that even operations executed by the public sector have their price and that both the public and the private sector need at least to cover their costs, leads to efforts to implement cost covering fees in the cadastre. This has been realised in some developed countries, for example in the countries of the former socialist block, where nearly every country in the region collects more in fees for service than their operating costs (Aldington, 2014). In many other developed countries, the aspect of cost recovery is still heavily discussed and no final and broadly accepted solution has been implemented yet. Cadastre 2014 has initiated many discussions concerning licenses and fees. It, however, proved to be too ambitious to recover all the costs including the investment in data acquisition. Therefore, the implementation of Statement 6 concentrates on recovering on-going costs and if possible a small part of the investment (Kaufmann, 2014).

\section{Related Work}

Nations worldwide have engaged in different forms of cadastral reform for two main reasons namely (1) the establishment of efficient land markets and (2) the necessity of modernising land administration systems (Williamson, 2001). Modern land administration systems (LAS) can better cope with dynamic land tenure arrangements due to continued evolution of mankind and the increased volumes of land information to be managed and maintained. The volumes of land transactions has increased thus rendering need for development and adoption of information technology based land 
administration systems. Williamson (2001) discusses key strategies that can be employed in the development of modern land administration systems such as (1) Strategies differ with context since countries have varying land tenure arrangements. These different land tenure arrangements have to be identified first., (2) The need to consider that the identified tenure arrangements are not static but rather dynamic requiring specific visions when developing of the LAS and (3) the level of development of the country which has a bearing on the land administration response and best practices suitable for the specific country. The Cadastral system should be focused on the efficient and timely performing of land transactions (Bevin, 1999) while it provides a one stop shop to the public for all cadastre related services (Chimhamhiwa, 2002). Modern cadastres should be tailored to facilitate efficient land markets and efficient land use administration. Enemark and Sevatdal (1999) view a cadastre as the basic infrastructure for providing economic and sustainable benefits.

The Core Cadastral Domain Model (CCDM) was developed in order to refine the generic guidelines outline in the Cadastre 2014 vision into a specific model as part of the development of future and modern land administration systems. The CCDM covered land registration and cadastre with two major aims of ensuring that nations have a common standard and platform for cadastral systems development and enabling communication between parties based on shared ontology proposed by the model (Lemmen and van Oosterom, 2006). The cadastre 2014 statements are discussed in detail in section 3.

The cadastre is according to (FIG, 1995) "a parcel based, and up-to-date land information system containing a record of interests in land. It usually includes a geometric description of land parcels linked to other records describing the nature of the interests, the ownership or control of these interests and often the value of the parcel and its improvements". Cadastral reform activities in the late 1990s were aimed at conversion from manual to digital cadastres as part of larger land information systems. These modern cadastres would then provide reliable land information in support of sustainable development and enhanced land management. The need to perform reforms was due to increase in population and pressure on land and the need to better manage land and other natural resources. In this regard, traditional cadastres were deemed unsuitable to meet the demands of sustainable development. On the other hand, the world and tenure arrangements in particular, are in a state of continuous development and as such cadastral systems need to adapt to these changes (Kaufmann, 1999).

Within the Northern Territory in Australia, the cadastral reform agenda was aimed at reforming the cadastral survey and land title systems through the development of a modern land administration system and the conversion of analogue data sets to digital format. The land administration system would then offer a one stop shop for land information to all stakeholders (West and Sarib, 2001). Jones et al., (1999) recognise the role of the cadastre as centred in delivering certainity and security to a country's land market. Jones and colleagues define cadastral reform as "a process through which 
the principles governing the nature and purpose of the cadastre are amended or revised". The reform is initiated by a societal need though changes and developments in technology can be catalysts towards reforms.

\section{Research Methods}

The research was carried out using the case study approach proposed by Yin (2003). The boundaries of the case study were defined by focusing attention on the major players in cadastral process and their roles as described by (Chimhamhiwa, 2002). These are the department of the Surveyor General (DSG), Local Planning Authorities (LPAs), Deeds Registry, Private Planners, Private Land Surveyors and Notaries. The term local planning authority refers to and is used interchangeably with a municipality.

The study set out to find the similarities and differences between the cadastral framework in Zimbabwe and the Cadastre 2014 conceptual framework. An attempt was made to compare and contrast the conformity of the Zimbabwe cadastral framework with the provisions of the Cadastre 2014 concept. The theoretical propositions in relation to modernising Zimbabwe's land administration document were derived from Cadastre 2014 concepts and have been set out as recommendations in section 8 . However, the propositions made stretch beyond Cadastre 2014 to include other theoretical propositions derived from Cadastre 2014 concepts such as the CCDM and LADM.

The units of analysis include the technical, institutional and legal aspects of the cadastre together with the guiding policies. These were examined in the context of the six statements of Cadastre 2014 and extensions thereof contained in other international guidelines and standards. The results of the study are reported with reference to the six statements of Cadastre 2014 in section 7. Primary data was collected through interviews and questionnaires while secondary data was collected from policy documents and reports. The study also relied on the experiences of the authors as land administration professionals in the surveying domain in Zimbabwe. The research also makes use of scholarly articles on land administration in Zimbabwe to give more context to the problem such as (Chimhamhiwa, 2002; Chimhamhiwa, 2006; Paradzayi, 2007; Kurwakumire, 2014; Kurwakumire and Kuzhazha, 2015).

\section{Key cadastral Processes in Zimbabwe}

According to (Chimhamhiwa, 2002), the four key cadastral processes that support the cadastral system in Zimbabwe are subdivisions, consolidations, sectional title surveys and whole parcel transfers. Private Planners, planning departments within Local Planning Authorities (LPA), private land surveyors, the Department of the Surveyor General (DSG), Notaries, Real estate agents and the Deeds Registry are the key institutions in the execution of cadastral processes. The Ministry of Lands 
and Rural Resettlement (MLRR) have emerged as another important institution under the "fast track" land reform programme. With the exception of planners, land surveyors, notaries and real estate agents, all other institutions within the cadastral process fall within the public sector.

Figure 1 shows the general cadastral workflow in Zimbabwe. A request falling under either subdivisions or consolidations is submitted through a Planner who drafts a permit and submits it to a Local Planning Authority for approval in terms of the Regional, Town and Country Planning Act (Chapter 29:12). On approval, a permit for subdivision or consolidation is issued by the Local Planning Authority. The approved permit is forwarded to a licensed Land Surveyor who undertakes the new boundary demarcation according to the provisions of the Land Survey Act (Chapter 20:12). A survey record consisting of the original field book, cadastral plans and other documents is compiled by the Surveyor and lodged as hard copies at the Department of the Surveyor General for examination and approval. On approval, a copy of the diagram is sent to the Local Planning Authority concerned and another to the permit holder. The permit holder will then forward the approved diagram to a notary for deed drafting. The draft deed is then submitted to the Deeds Registry for examination and approval. Once approved ownership is transferred and the new deed handed over to the new owner.

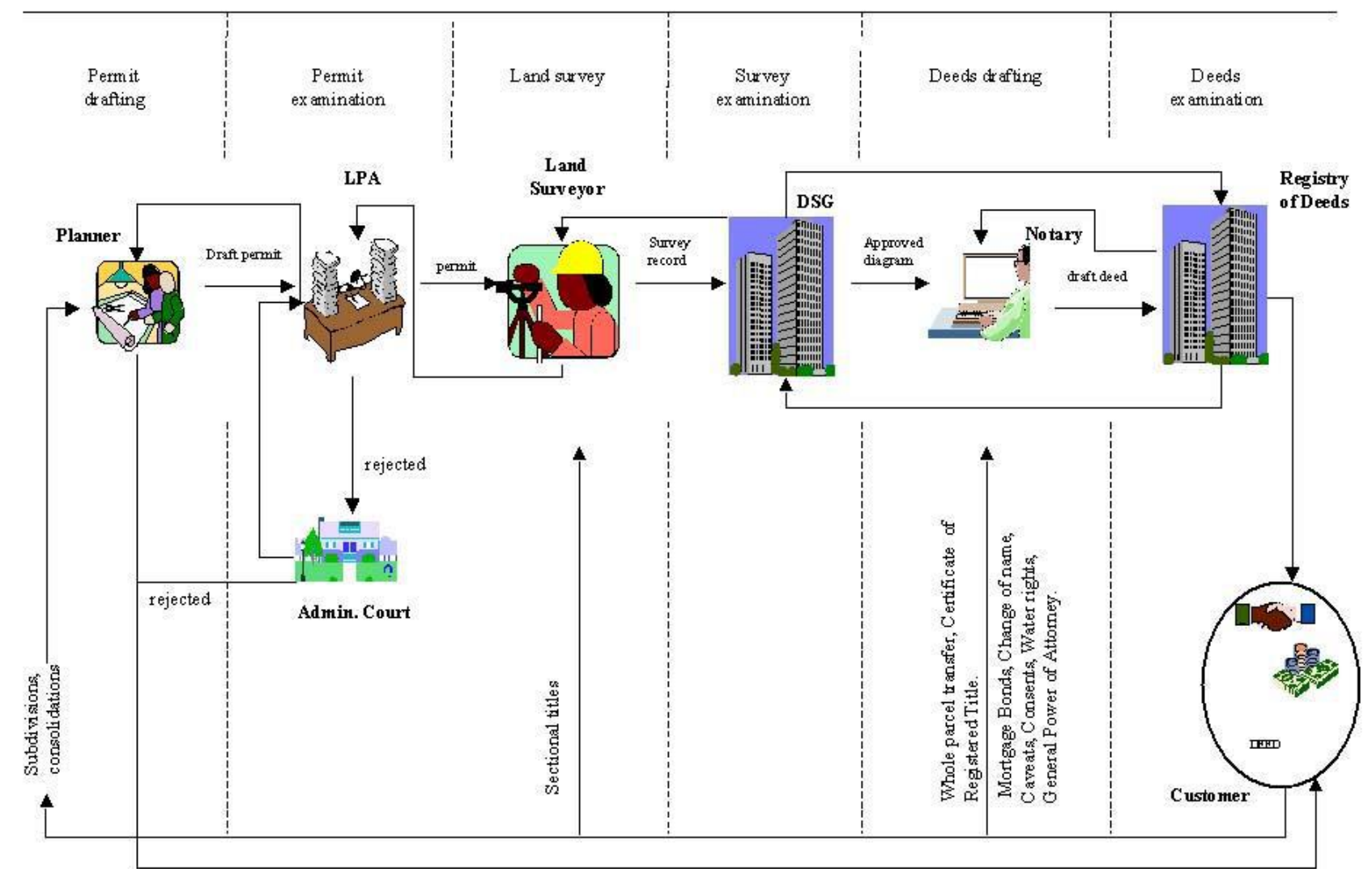

Figure 1: Key cadastral processes in Zimbabwe - Source: (Chimhamhiwa, 2002)

Sectional titles are processed by the Land Surveyor who demarcates the boundaries and prepares the required survey records. The survey records are then lodged with the Surveyor General for 
examination and approval. Whole parcel transfers and related transactions are lodged directly with the Deeds Registry (Chimhamhiwa, 2002).

Public sector institutions are responsible for the examination and storage of land information. The preparation of information is usually subcontracted to the private sector with the public sector retaining the key responsibility of assuring quality. Local planning authorities regulate the use and development of land by granting permits and defining land use zones.

The Department of the Surveyor General and the Deeds Registry fall under different government ministries and run exclusive operations. The Department of the Surveyor General is responsible for supervising the survey and charting of land for purposes of registration in the Deeds Registry and is also the custodian of all records pertaining to the survey of such land. The Deeds Registry is responsible for the registration of all transactions affecting land. Local planning authorities are responsible for maintaining valuation roles but land value information is also captured through registration processes when land is transferred from one party to another. Land related transactions are generally analogue.

\section{Comparison of Zimbabwe Cadastral System and Cadastre 2014}

\subsection{Statement 1}

Cadastre 2014 will show the complete legal situation of land, including public rights and restrictions.

In most cases, public restrictions in Zimbabwe emanate from planning regulations that are created and enforced by Local Planning Authorities or by the Department of Physical Planning. These institutions are empowered by various statutory instruments mainly the Regional, Town and Country Planning Act and the Urban Councils Act to make regulations regarding land use zoning, noise restrictions, ground water protection and others directing development in their areas of jurisdiction. These public restrictions are mainly land use restrictions such as residential, industrial, commercial and agricultural. These restrictions also stipulate the type of developments by specifying the building type and size within a particular zone. These restrictions are not recorded in the cadastre and land registry in Zimbabwe.

In some cases, public rights and restrictions emanate from other governmental organisations empowered by statutory instruments such as the Communal Land Act which protects indigenous land rights and the Environmental Management Act which sets regulations for the protection of the environment. Other statutory instruments such as the Water Act, the Road Act and the Fencing Act also create public rights and restrictions which are also not part of the information recorded in the cadastre and land registry. 
Although most local planning authorities agreed that the planning of these rights and restrictions follow cadastral boundaries or clearly defined physical features, the Land Survey Act and the Deeds Registries Act which regulate the survey and registration of land in Zimbabwe do not stipulate the registration procedures of such rights. There is no evidence in the current policies and practices that these rights and restrictions will be included in the national cadastre any time soon. However, this study established that in most institutions the available human resources are adequately qualified to handle the administration of such rights.

The cadastre is Zimbabwe is used for recording all rights relating to formal tenure arrangements, thus communal land for example, is not considered for registration. All cadastral information that is achieved as a result of lodged and examined surveys are kept at the Department of the Surveyor General such that non-title surveys are not recorded. In Zimbabwe, all private rights leading to deeds registration are recorded while some public rights and restrictions are not. The rights recorded and included in the Zimbabwe cadastre include ownership rights, servitudes including rights of way and mortgages. However, a considerable number of properties within urban areas are not registered for title as there is no link to land development procedures by Municipalities to the registration process involving the Department of the Surveyor General and the Deeds Registry. There is need to develop a framework which ensures that, land sold to the public is registered either before occupation (if the banking sector is included to finance housing) or to transfer the title to individuals after the cost of the property has been paid up.

\subsection{Statement 2}

The separation between maps and registers will be abolished.

The separation between cadastral maps and land registers still exists in Zimbabwe. Although efforts are underway to develop a networked environment that links the Department of the Surveyor General and the Deeds Registry, at the present moment hundred percent of data exchange between the two departments is still in hardcopy format. In addition the two departments still operate under different statutory instruments and ministries. No single authority has been created to coordinate the integration of information between the two organisations. The Department of the Surveyor General still operates under the Ministry of Lands and Rural Resettlement and the Deeds Registry still operates under the Ministry of Justice and Legal Affairs. There is need for a land information system which links the operations from the cadastral processes done through the Department of the Surveyor General and the rights procedures done through the Deeds Registry. In this regard, there is no one stop shop regarding land transactions as both organisations need to be visited in order to complete the transaction. 


\subsection{Statement 3}

The cadastral mapping will be dead. Long live modelling.

Most respondents displayed limited understanding of data modelling techniques. Since the term itself is little understood, it follows that the goal is far from being achieved. However, the Department of the Surveyor General has set standards on what constitutes cadastral diagrams. The quality of the diagrams is checked through the process of examining surveys for approval by the Surveyor General. Modelling software is non-existent amongst the different professionals. Maps are created using CAD software with the main programs in use being Surpac and AutoCAD. Traditionally, digital information is stored as unstructured computer files that will be printed for onward transmission to other departments. Recent studies have indicated that it is possible to develop a country profile for cadastral modelling in Zimbabwe through adopting the Land Administration Domain Model (LADM) ISO 19512 standard in the Zimbabwean context. Efforts are underway to develop a LADM country profile for the Zimbabwe according to (Paradzayi et al., 2014).

Recently major municipalities have been adopting the use of Geographic Information Systems (GIS) for the capture and management of Cadastral and other spatial data. These municipalities include Bulawayo, Harare, Gweru, Kadoma and Kariba (Kurwakumire and Kuzhazha, 2015). However, while this adoption of GIS is being done which involves manipulation of cadastral data sets, no particular national model exists to ensure uniformity in the objects being represented and their results. This can be defined in the development of conceptual framework for land information system design that is based on an international model.

\subsection{Statement 4}

Paper and pencil cadastre will have gone.

The cadastral drafting process has improved greatly in light of this statement. Paper and pencil methods of drafting have been replaced by drafting software. All interviewed Land surveyors indicated that they now use CAD software to prepare cadastral plans. However the Land Survey Regulation of 1978 still does not provide for lodgement of digital data and so Land Surveyors are required to transmit only hard copy printouts of information that was created in digital format in the first place. Therefore the digital data that must form the modern land administration system remain with the Land Surveyors as unstructured computer files as there is no central database to deposit the information.

Other professionals such as real estate managers and notaries indicated no challenges with automating their procedures and documentation if automation is spearheaded by leaders in the 
geospatial community such as the Department of the Surveyor General, Town Planners and Land Surveyors. However, the facts on the ground require workflow re-engineering, systems development and updating of legislation to allow for digital documents and signatures in the land transaction system in order to migrate to a computerised system.

With the adoption of GIS in municipalities, Zimbabwe is on its way towards a paperless office. However, there exists a challenge in the appropriate infrastructure to facilitate easy sharing and exchange of information within and outside organisational boundaries. In this regard, there is need for development of webGIS systems as proposed in (Kurwakumire, 2013) towards a larger and even more robust infrastructure namely, the spatial data infrastructure. This will promote sharing and reuse spatial data and in particular, cadastral data.

\subsection{Statement 5}

Cadastre 2014 will be highly privatized. Public and private sector are working closely together.

There exists some level of partnership between the public and private sector regarding operations of the Cadastre and Deeds Registry. Most cadastral surveys are carried out by private land surveyors on behalf of the Department of the Surveyor General and the majority of deeds are prepared by private notaries. Even some responsibilities that were previously the prerogative of the public sector are being delegated to private land surveyors, for example approving survey records. It may prove more efficient to outsource system development as the departments do have adequate capacity for such a project. However, the private sector will still need to work with the Department of the Surveyor General, Deeds Registry and other stakeholders throughout the design up to full implementation when system handover is done.

\subsection{Statement 6}

\section{Cadastre 2014 will be cost recovering.}

The revenue generated by both the Department of the Surveyor General and the Deeds Registry through search fees covers less than twenty five percent of the expenses incurred in gathering and storing the information (Magumise, 2014). Search fees relates to the cost paid in order for records and maps to be retrieved. Concepts of cost recovery are quite well understood but the means to achieve good levels of cost recovery seem to be lacking. There lacks an electronic billing system which could facilitate more transparency in transactions while keeping a record of products that are often demanded which can then be turned into focus areas by the Department of the Surveyor General (DSG). The DSG needs to offer a wide range of products and services which enable it to raise sufficient income to be cost recovering. However, consideration should be given to the fact that cadastral information is still public information and should thus be affordable to the general public as 
well. Excessive survey fees discourage the public from obtaining deeds of ownership which has a negative impact on the revenue to be generated by the DSG based on Surveys from individuals that are lodged for examination and approval. The Department of the Surveyor General should in essence, develop a cost recovery framework which is connected to a pricing strategy of different products and services while considering the standard income of the ordinary citizen.

\section{Recommendations for best practices to be adopted in Zimbabwe.}

i. Since most public rights are structured to follow cadastral boundaries or some welldefined physical features, land surveyors and other land administration practitioners must be tasked to prepare diagrams representing the extent of these rights and restrictions using a wide range of methods to include coordinates from land survey, aerial photographs and satellite imagery. The public rights cadastre must be integrated with the existing cadastre based on a common reference system.

ii. A single government agency can ideally spearhead the integration of cadastral maps and the land register. Otherwise a partnership between the DSG and the Deeds Registry is possible. In this case, the DSG will create and maintain cadastral information and will be its custodian. On the other hand, the Deeds Registry will create and maintain all rights information. The fees of examination of surveys and those paid in different land transactions leading to registration of the deeds can be employed in maintaining this land information system. In this regard, the cadastre and land registry will be viewed as one and the public will only have to visit one organisation in order to access land related services. The departments should built adequate capacity for the implementation and maintenance of the land information system as it is a public good infrastructure necessary for the social and economic development of the country. The Land Survey Regulations must be amended to allow for digital lodgement of cadastral data sets that can be used to build the cadastral data model. Hardcopy datasets will need to be digitized for integration in the system.

iii. Greater attention must be addressed to cost recovery aspects of the cadastre. Realistic search fees must be prescribed in order to recover a reasonable percentage of the costs incurred in the preparation and storage of cadastral information.

iv. The research revealed that Zimbabwe has adequate skilled human resources in the surveying profession, however they opt to render their services in the private than in the public sector due to significant differences in the remuneration packages offered by the two sectors. Since the collection, creation, management and maintaining of spatial data is a collective effort involving many organisations from different sectors (Kurwakumire et al., 2013), public- 
private partnerships should be explored in order to have timely access to quality spatial data as per the client's request.

v. Digitizing of all fundamental or base data sets: This issue can be coordinated by the DSG at national level, while municipalities are responsible for data capture within their local jurisdictions. There is need to set standards regarding to digitising such as the coordinate system, projection, digital data formats and metadata component. It is possible for municipalities to maintain particular the cadastral data sets as however, this information needs to be deposited in a central repository to be established at the DSG so that this information is available to a wider audience. This repository is referred to as the Spatial Data Infrastructure (SDI). In support of data maintenance and the SDI at large, there is need to identify several data custodians who maintain different fundamental data sets in terms of ensuring its quality, timeliness and accessibility to different stakeholders.

vi. Development of a nationwide database for land information to be maintained and managed by the DSG. However partnerships with stakeholders such as real estate agencies, land development firms and banks are needed to ensured successful implementation and maintenance rather than relying on the government only. This database should be linked to the land transaction and digital lodgement of surveys among other important system modules.

vii. Creation of one stop shop for land transactions and other cadastre related services

viii. Introduction of Service Kiosks and web platform facilitated by ecommerce for access of cadastral services

ix. Re-engineering the land transaction workflow so that the time to complete a secure transaction and for land to exchange hands is greatly reduced.

x. Development and adoption of land administration model country profile that is used as a basis for systems design. This will ensure communication and uniform application of standards between different stakeholders such as Municipalities, DSG, Deeds Registry and MLRR. All systems will be then based on the same conceptual schema. A country profile based on the LADM is under development from a research point of view (Paradzayi et al., 2014).

xi. Amend surveying regulations so that they do not prescribe the technology for use in carrying out surveys of land. Rather the regulations should encourage the use modern technology in taking measurements on the earth's surface. Modern technology, produces data in digital format, which can be directly exported to CAD software and processed into the final 
product which can in principle be lodged in digital form at the DSG. The DSG can go on further to perform examination on these digital documents and store them in a data warehouse after approval for public access. In this way, Zimbabwe can then achieve a paperless office which contributes to the abolishment of paper and pencil cadastre stipulated in statement 4 of cadastre 2014.

xii. Development of a building register so that all buildings are registered including their respective values.

\section{Conclusions}

Zimbabwe is still lagging behind with regard to fulfilling the standards stipulated by Cadastre 2014 through the six statements. While some of the goals set by Cadastre 2014 have been partially fulfilled, this has not been through a deliberate effort to implement Cadastre 2014 principles. As attention shifts to Cadastre 2034, Zimbabwe must accelerate the implementation of Cadastre 2014. The development of a modern land administration system is key to realising the goals set by cadastre 2014. Such a move will set the country on an even ground to adopt Cadastre 2034. There is need for land administration officials to realise that the relationship between mankind and land is in constant evolution. This fact should be taken into consideration in the development of land administration systems of the future. Current tenure arrangements need to be examined to ensure that they are sustainable and they manage and preserve land and other resources for generations yet to come. This study established that Zimbabwe has adequate human resources within the land administration domain to meet the requirements of Cadastre 2014 and other international standards. A good governance in land framework supported by relevant ministries is required to realise the set of goals stipulated in the cadastre 2014 vision. Land administration practitioners in Zimbabwe must take the initiative to workshop policy makers on the importance of efficient cadastral systems for national development especially in view of the goals set out in the ZIMAsset economic blue print.

\section{References}

Adlington, G 2014, 'Case studies from newly renovated land administration systems in the emerging economies', in D Steudler (ed), Cadastre 2014 and Beyond, International Federation of Surveyors, FIG Publication No. 61, Wabern, Switzerland.

Bennett, R 2014, 'Cadastre 2014: What Lies Beyond?', in D Steudler (ed), Cadastre 2014 and Beyond, International Federation of Surveyors, FIG Publication No. 61, Wabern, Switzerland.

Bevin, T 1999, 'Cadastre 2014 Reforms in New Zealand', New Zealand Institute of Surveyors \& FIG Commission VII Conference \& AGM Bay of Islands, 9-15th October 1999

Chimhamhiwa, D 2002, 'Cadastral Reform for Sustainable Land Redistribution - Case of Zimbabwe', International Federation of Surveyors - FIG Commission 7, Pretoria. 
Chimhamhiwa, D 2006, 'Benchmarking for Regional Best Practice - Comparative Evaluation of Land Administration Systems in Namibia, South Africa and Zimbabwe', Shaping the Change - XXIII FIG Congress Munich, Germany, 8 - 13 October 2006

Dekker, M 2009, 'Livelihoods and economic crisis: the case of smallholder farmers in Zimbabwe (1999 2008)', Paper for the conference - Economic Development in Africa, Centre for the study of African Economies, University of Oxford, 22-24 March 2009

Enemark, S \& Sevatdal, H 1999, 'Cadastres, Land Information Systems and Planning - Is Decentralisation a Significant key to Sustainable Development', UN-FIG Conference on Land Tenure and Cadastral Infrastructures for Sustainable Development, Melbourne, 25-27 October 1999.

FIG 1995, 'The FIG Statement on the cadastre', FIG Publication Services No. 11, The Surveyor's House, Copenhagen.

Government of Zimbabwe 2013, 'Zimbabwe Agenda for Sustainable Socio-Economic Transformation (ZimAsset)', Government Printers, Harare.

Hull, S \& Whittal, J 2013, 'Good e-Governance and Cadastral Innovation: In Pursuit of a Definition of eCadastral Systems', South African Journal of Geomatics, Vol. 2, No. 4, pp. 342 - 357.

Jang, B \& Koh, J 2014, 'Cadastre 2014 - A case study from South Korea', International Federation of Surveyors, Denmark.

Jones, LJ 2010, 'Nothing is Straight in Zimbabwe: The Rise of the Kukiya-Kiya Economy 2000 - 2008', Journal of Southern African Studies, vol. 36, no. 2, pp. 285 - 299.

Jones, A, Rowe, C \& Kentish, P 1999, 'Cadastral Reform', Discussion paper for the ICSM, Intergovernmental Committee on surveying and Mapping.

Kaufmann, J \& Steudler, D 1998, 'Cadastre 2014: A vision for a future Cadastral System', Working group 1 of FIG Commission 7, Switzerland.

Kaufmann, J 1999, 'Future Cadastres: Implications for future Land Administration Systems - Bringing the world together?', UN-FIG Conference on Land Tenure and Cadastral Infrastructures for Sustainable Development, Melbourne, Australia, 25-27 October 1999.

Kaufmann, J 2014, 'Review and Impact of the Six Statements of Cadastre 2014', FIG Congress 2014: Engaging the Challenges - Enhancing the Relevance, Kuala Lumpur, Malaysia, 16-21 June 2014.

Kurwakumire, E \& Chaminama, N 2012, 'An Analysis of Data Handling Techniques in Zimbabwe', FIG Working Week 2012 - Knowing to manage the territory, protect the environment, evaluate the cultural heritage, Rome, Italy, 6-10 May 2012.

Kurwakumire, E 2013, 'WebGIS Enabling Information Sharing in Local Government', SASGI Proceedings

2013, Kempton Park, South Africa, 23-24 July 2013.

Kurwakumire, E, Coetzee, S \& Schmitz, P 2013, 'Towards Modelling the SDI Supply Chain in South Africa: The Case of Land Administration Data', in H Onsrud (ed), GSDI 2014 Proceedings, GSDI, Addis Ababa, Ethiopia, 4 - 8 November 2013.

Kurwakumire, E 2014, 'Digital Cadastres Facilitating Land Information Management', South African Journal of Geomatics, vol 3, no. 1, pp. 64 - 77.

Kurwakumire, E \& Kuzhazha, S 2015, 'Cadastral Systems Re-engineering in Urban Zimbabwe', South African Journal of Geomatics, vol 4, no. 4, pp. 434 - 449.

Lemmen, C 2012, 'A domain model for land administration', PhD Thesis, ITC, Netherlands.

Lemmen, C \& van Oosterom, P 2006, 'Version 1.0 of the FIG core cadastral domain model', Shaping the Change - XXIII FIG Congress, Munich, Germany, 8-13 October 2006.

Magumise, B 2014, 'Cadastre 2014: Reflections on a passing surveying landmark for Zimbabwe', Honours Dissertation - Department of Surveying and Geomatics, Midlands State University, Gweru, Zimbabwe.

Paradzayi, C 2005, 'Spatial Data Infrastructure as a vehicle for Sustainable Development in Zimbabwe', FIG Working Week 2005 - From Pharaohs to Geoinformation, Cairo, Egypt, 16-21 April, 2005. 
Paradzayi, C 2007, 'Land Tenure in Zimbabwe's Post Agrarian Reform', FIG Working Week 2007 - Strategic Integration of Surveying Services, Hong Kong SAR, China, 13-17 May 2007.

Paradzayi, C, Mapamula, RT, Mtariswa, T 2014, 'Investigating the Conformity of the Zimbabwe Land Administration System to the Land Administration Domain Model Standard (ISO 19152)', FIG Congress 2014, Engaging the Challenges - Enhancing the Relevance, Kuala Lumpur, Malaysia, 16 - 21 June 2014. Regional, Town and Country Planning Act of 1996, Chapter 29:12, Government Printers, Harare, Zimbabwe. Steudler, D 2014, 'Developments out of Cadastre 2014 Internationally and in Switzerland in Particular', in D Steudler (ed), Cadastre 2014 and Beyond, International Federation of Surveyors, FIG Publication No. 61, Wabern, Switzerland.

van der Molen, P 2006, 'Tenure and Tools, two aspects of innovative land administration', RICS, London, United Kingdom, 13 December 2006.

van der Molen, P 2014, 'Cadastre 2014: A beacon in Turbulent Times', in D Steudler (ed), Cadastre 2014 and Beyond, International Federation of Surveyors, FIG Publication No. 61, Wabern, Switzerland.

West, G \& Sarib, R 2001, 'A Spatial Odyssey', 42 ${ }^{\text {nd }}$ Australian Surveyors Congress

Williamson, I. P. "The evolution of modern cadastres." Proceedings of New Technology for a New Century Conference, FWW2001, Seoul, South Korea. 2001.

World Bank 2006, 'Where is the wealth of nations? - Measuring Capital for the $21^{\text {st }}$ Century', The World Bank, Washington DC

Yin, RK 2003, Case study research: design and methods, Sage, Newbury Park. 